\title{
Polyphyly of the genus Zanclea and family Zancleidae (Hydrozoa,Capitata) revealed by the integrative analysis of two bryozoan-associated species
}

\author{
Davide Maggioni $^{1,2,4}$, Roberto Arrigoni $^{3}$, Paolo Galli ${ }^{1,2}$, Michael L. Berumen $^{3}$, Davide Seveso $^{1,2}$, Simone Montano $^{1,2}$ \\ ${ }^{1}$ Marine Research and High Education (MaRHE) Center, Faafu Magoodhoo 12030, Republic of the Maldives \\ ${ }^{2}$ Dipartimento di Scienze dell'Ambiente e del Territorio (DISAT), Università degli Studi di Milano-Bicocca, Milano \\ 20126, Italy \\ ${ }^{3}$ Red Sea Research Center, Division of Biological and Environmental Sciences and Engineering, King Abdullah \\ University of Science and Technology, Thuwal 23955-6900, Saudi Arabia \\ ${ }^{4}$ E-mail: davide.maggioni@unimib.it
}

Keywords: Anthoathecata, Maldives, molecular phylogenetics, Red Sea, Zanclella

\begin{abstract}
The Zancleidae is a hydrozoan family that currently comprises three genera and 42 nominal species. The validity of numerous taxa in this family still needs to be assessed with integrative analyses and complete life cycle descriptions. The vast majority of its species live symbiotically with other organisms, among which cheilostomate bryozoans are the most common hosts. These bryozoan-associated zancleids are host-specific and encompass all species of the genera Halocoryne and Zanclella, as well as several species in the genus Zanclea. Zancleids show variable morphologies, including highly reduced polyps and medusae. Their phylogenetic history is uncertain due to the often intergrading morphologies and the shortage of molecular data. In the present study, two species of Zanclea from the Indian Ocean and the Red Sea are analysed, using morphological and DNA-based approaches. Morphological analyses of the polyp and medusa stages show that, despite a general resemblance with each other and with Zanclella diabolica, the two species differ in some characters, and this is supported also by molecular investigations. The DNA analyses show that the two species are monophyletic and closely related, but divergent from other Zanclea lineages. This newly recovered clade may correspond with the genus Zanclella or with a cryptic genus. The lack of both morphological and molecular data for several zancleid species did not allow to address this issue. Additionally, the singleand multi-locus phylogeny reconstructions reveal that both the family Zancleidae and the genus Zanclea are polyphyletic taxa, since they are composed of at least three divergent lineages. Most zancleid species have polyps and medusae similar to other closely related taxa, and this conserved general morphology poses a challenge in the delimitation of species, genera and even families in this group. Consequently, further conjunct morphological and molecular efforts are strongly needed to clarify the diversity and evolution of the family Zancleida as a whole.
\end{abstract}

\begin{abstract}
Contents

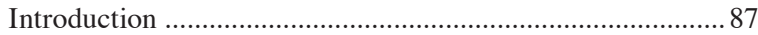

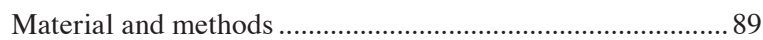

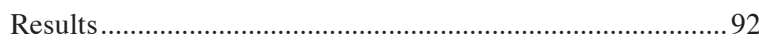

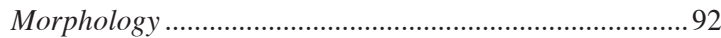

Phylogeny and genetic diversity ................................... 94

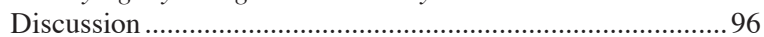

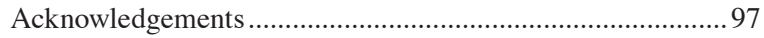

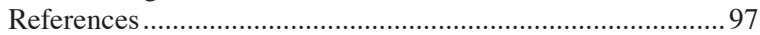

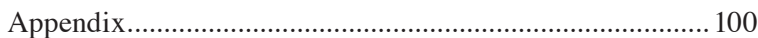

\section{Introduction}

The Zancleidae (Russel, 1953) is a family of capitate anthoathecate hydrozoans with a complex and confusing taxonomy. Throughout the years, various authors have defined Zanclea species using conservative approaches, in some cases including multiple species into a unique 'variable' taxon (Russel, 1953) and in other cases describing several new species (Boero et al., 2000) and new genera (Boero and Hewitt, 1992). The family currently comprises 42 nominal species grouped in three genera: Zanclea Gegenbaur, 1856, Halocoryne Hadzi, 1917, and Zanclella Boero \& Hewitt, 1992. However, Schuchert $(1996,2010)$ argued against the separation of these three taxa based on morphology alone, since the characters used to discriminate them often intergrade. According to the family diagnosis given in Bouillon et al. (2006), all species in the Zancleidae are colonial, stolonal, with creeping hydrorhiza, and with or without a perisarc sheet covering the hydrocauli and hydrorhizae. Polyps can be monomorphic or polymorphic, and in some 


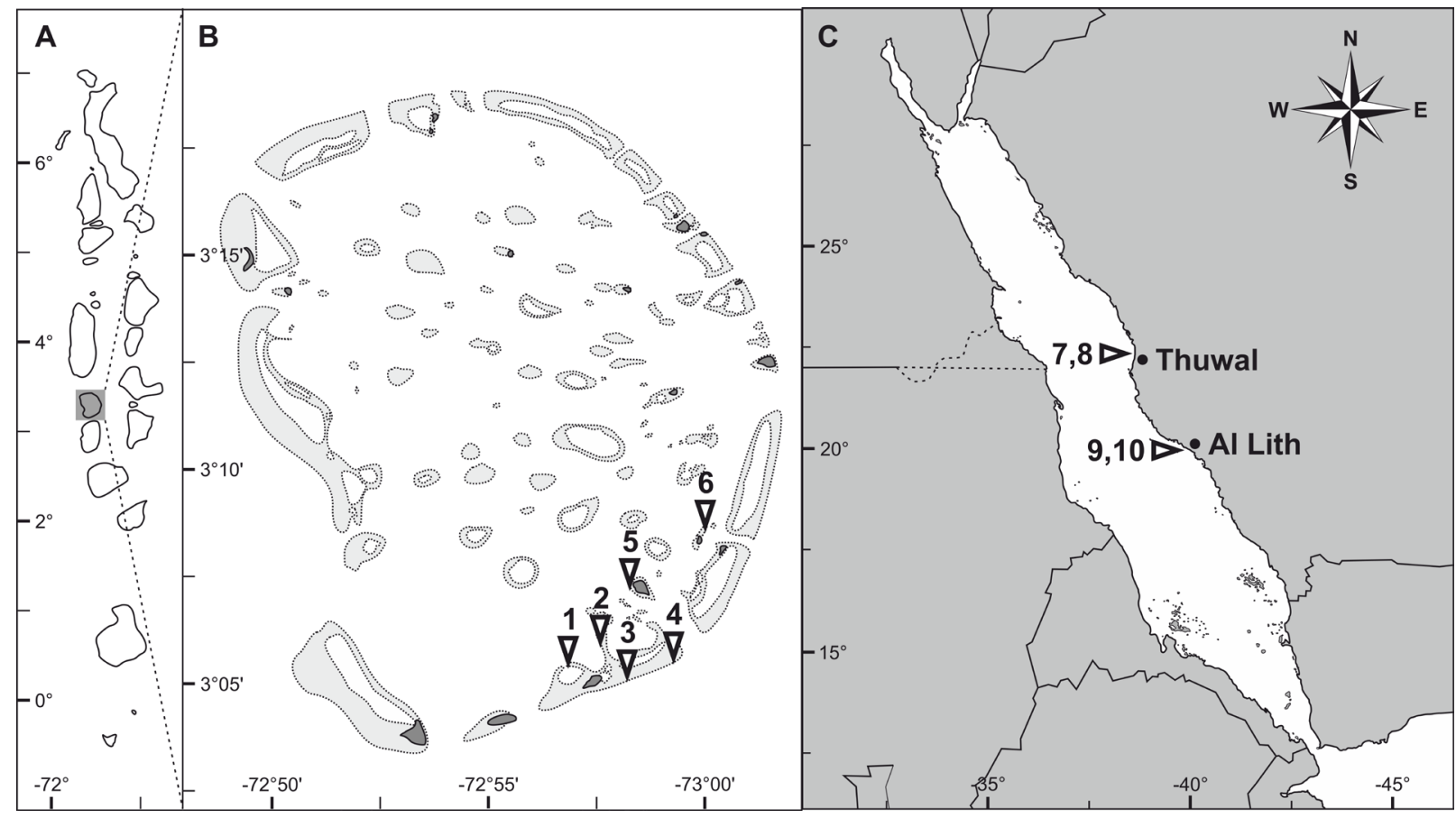

Figure 1. Maps of the investigated localities. A: Maldivian archipelago; B: Faafu Atoll; C: Red Sea. Numbers denote sampling sites. 1: Kika Reef; 2: Blue Cove; 3: Route 66 Reef; 4: Dhigu Reef; 5: Wall Street Reef; 6: Sunny Reef; 7: Tahla Reef; 8: Abu Gishaa Reef; 9: Abu Latt Island; 10: Sofia's Reef.

cases highly reduced. Medusae generally have a bellshaped umbrella and zero, two, or four tentacles. Tentacles, when present, are armed with cnidophores, and gonads are usually interradial. Some species of Zanclella and Halocoryne have undergone reduction in the polyp and/or medusa stages (Boero et al., 2000). Petersen (1990) observed that reductions in the medusa stage are common in anthoathecate hydrozoans (e.g. in the family Corynidae) but these do not qualify as valid generic characters, since they have likely occurred independently in different species lineages after the synapomorphies defining genera evolved. For instance, all known Halocoryne polyps lack tentacles, but only the reproductive stage of Halocoryne epizoica Hadzi, 1917 is represented by a short-living eumedusoid, whereas all other species show a completely developed medusa stage (Piraino et al., 1992; Boero et al., 2000). Zanclella has polyps with one or two tentacles, with the exception of Zanclella diabolica Boero, Bouillon \& Gravili 2000, which shows multiple oral and aboral tentacles, and the type species Zanclella bryozoophila Boero \& Hewitt, 1992 reproduces through an eumedusoid, contrarily to its congeners (Boero and Hewitt, 1992; Boero et al., 2000). Zanclella is separated from
Zanclea based on the reduced number of tentacles of the gastrozooids and the laterally compressed appearance of the umbrella of the medusa (Bouillon et al., 2006), but these features cannot be applied reliably to all Zanclella species, and, as suggested by Schuchert (1996, 2010), Zanclella should be regarded as a synonym of Zanclea. Similarly, Schuchert (2010) also highlighted that an evaluation of the relationships of Halocoryne species with other Zancleidae is impeded by the reduction of both the polyp and medusa stages. A proper molecular phylogeny of the three genera may therefore help resolving this uncertainty. Indeed, the taxonomic confusion is exacerbated by the fact that DNA sequences are available only for a few Zanclea species, whereas no molecular data have been generated so far for any Zanclella and Halocoryne species.

The majority of zancleid species live in strict association with other organisms, and the relationships with their hosts span from a presumable mutualism (Osman and Haugsness, 1981; Ristedt and Schuhmacher, 1985; Montano et al., 2017a) to parasitism (Piraino et al., 1992). Among the 30 species with a described benthic polyp stage, 16 are specifically associated with bryozoans (Boero et al., 2000; Puce et 
al., 2002; Pica et al., 2017), four with scleractinians (Boero et al., 2000; Pantos and Bythell, 2010; Hirose and Hirose, 2011; Montano et al., 2015a), two with octocorals (Puce et al., 2008; Varela, 2012), two with bivalves (Boero et al., 2000), two with algae (Boero et al., 2000; Galea, 2008), while four other show no substrate specificity (Agassiz, 1862; Schuchert, 2010; Peña Cantero et al., 2013). In particular, Halocoryne and Zanclella species live symbiotically with bryozoans and are thought to have derived from Zanclea species associated with bryozoans and with a perisarc-free hydrorhiza protected by the skeleton of the host (Puce et al., 2002). Indeed, all species in these two genera have their naked hydrorhizae embedded in the skeleton of the host (Boero et al., 2000), and this aspect, together with the presence of highly modified polyps and medusae, and the behavioural integration with the bryozoan (Boero and Hewitt, 1992; Piraino et al., 1992), are considered as derived traits among the Zancleidae (Boero et al., 2000; Puce et al., 2002). Overall, several aspects of this enigmatic family need to be investigated further in more detail, particularly regarding the evaluation of its diversity, systematics and evolution.

The current work aims to characterise two bryozoanassociated zancleid species similar to Zanclella diabolica based on specimens collected in the Indian Ocean and Red Sea. The aim is to investigate their placement within the superfamily Zancleida and present an updated phylogenetic assessment of the family Zancleidae.

\section{Material and methods}

Specimen sampling was conducted between December 2015 and May 2017 in Faafu Atoll (Maldives) and in reefs surrounding Thuwal and $\mathrm{Al}$ Lith (Red Sea, Saudi Arabia) (Figure 1). The presence of hydroids on bryozoans was recorded qualitatively in situ, and small fragments of bryozoans hosting hydrozoans were collected with hammer and chisel. After anesthetisation with menthol crystals, single hydrozoan polyps were carefully collected one by one using syringe needles, precision forceps, and micropipettes, directly from a bowl filled with seawater that was placed under a stereomicroscope. Afterwards, they were preserved in $95 \%$ ethanol for molecular analyses and $10 \%$ formalin for morphological studies. Additional portions of colonies were cultured and fed Artemia nauplii in small bowls at the MaRHE Center (Magoodhoo Island, Faafu Atoll, Maldives) in order to observe the release of medusae. Thereafter, the medusae were maintained in small bowls, and the sea water was replaced every day. The reared medusae were observed on a daily basis and some of them were fixed in $10 \%$ formalin. Morphological observations and pictures of polyps, medusae, and nematocysts were mainly performed on living specimens, whereas measurements were taken on formalin-fixed material. Photomicrographs of hydroids, medusae, and nematocysts were taken using a Leica EZ4 D stereomicroscope and a Zeiss Axioskop 40 compound microscope, both equipped with a Nikon AW 100 camera. Measurements were taken with a Nikon Eclipse E600 microscope using the NIS-Elements Viewer 4.30 software, and up to 20 specimens per species, and 50 nematocysts per type for each life stage of each species, were measured.

Tables including all available diagnostic characters for polyp and medusa stages of all the nominal zancleid species and the two species herein analysed (Supplementary tables S1, S2) were compiled by retrieving data from all the relevant literature (Agassiz, 1862; Haeckel, 1879; Browne, 1916; Hastings, 1930; Kramp, 1959; Uchida and Sugiura, 1976; Calder, 1988; Hirohito, 1988; Xu et al., 1991, 2008; Boero and Hewitt, 1992; Piraino et al., 1992; Gravili et al., 1996; Migotto, 1996; Cerrano et al., 1997; Schuchert, 1996, 2010; Boero et al., 2000; Puce et al., 2002, 2008; Gershwin and Zeidler, 2003; Galea, 2008; Pantos and Bythell, 2010; Hirose and Hirose, 2011; Varela, 2012; Altuna, 2013, 2016; Peña Cantero et al., 2013; Montano et al., 2015a; Pica et al., 2017).

Total genomic DNA of ethanol-fixed samples was extracted following a protocol modified from Zietara et al. (2000). Four different molecular markers were amplified: i) a $\sim 600 \mathrm{bp}$ portion of the mitochondrial $16 \mathrm{~S}$ ribosomal DNA gene (16S $r R N A)$, ii) a $\sim 700$ bp portion of the mitochondrial cytochrome $c$ oxidase subunit I gene $(C O X 1)$, iii) a $\sim 1700$ bp portion of the nuclear $18 \mathrm{~S}$ ribosomal DNA gene (18S rRNA), iv) a $\sim 1700$ bp portion of the nuclear $28 \mathrm{~S}$ ribosomal DNA gene (28S rRNA). $16 S$ rRNA and $28 S$ rRNA loci were amplified using hydrozoanspecific primers following the protocols described in Cunningham and Buss (1993) and Maggioni et al. (2016). COX1 and 18S rRNA genes were amplified using metazoan universal primers and the protocols proposed by Folmer et al. (1994) and Medlin et al. (1988), respectively. All PCR products were purified with Illustra ExoStar (GE Healthcare) at $37^{\circ} \mathrm{C}$ for 
Table 1. GenBank accession numbers of the sequences included in the analyses. Newly obtained sequences are in bold.

\begin{tabular}{|c|c|c|c|c|c|}
\hline \multirow[t]{2}{*}{ Family } & \multirow[t]{2}{*}{ Genus } & \multicolumn{4}{|c|}{ GenBank Accession Numbers } \\
\hline & & 16S rRNA & COX1 & 18S rRNA & 28S rRNA \\
\hline Asyncorynidae & Asyncoryne ryniensis & EU876552 & - & EU876578 & GQ424289 \\
\hline \multirow[t]{2}{*}{ Cladocorynidae } & Cladocoryne haddoni & LT593865 & LT593890 & LT593875 & LT593870 \\
\hline & Pteroclava krempfi & LT158199 & LT158209 & LT593876 & LT222039 \\
\hline Hydrocorynidae & Hydrocoryne miurensis & GQ395326 & - & - & GQ424313 \\
\hline Milleporidae & Millepora alcicornis & EU876551 & - & AF358088 & EU879950 \\
\hline \multirow[t]{2}{*}{ Moerisiidae } & Moerisia inkermanica & KT266626 & - & KT722408 & KT757161 \\
\hline & Odessia maeotica & GQ395324 & - & GQ424341 & GQ424314 \\
\hline Pennariidae & Pennaria disticha & KF962510 & KF962169 & KF962290 & KF962370 \\
\hline \multirow[t]{2}{*}{ Porpitidae } & Porpita porpita & AY935322 & GQ120060 & GQ424319 & EU883551 \\
\hline & Velella velella & EU305487 & KC706685 & EU876576 & EU879949 \\
\hline Solanderiidae & Solanderia secunda & EU305484 & JX121599 & EU305502 & EU305533 \\
\hline \multirow[t]{3}{*}{ Sphaerocorynidae } & Astrocoryne cabela & LT714176 & - & LT714177 & LT714178 \\
\hline & Heterocoryne caribbensis & LT714185 & MH248019 & LT714186 & LT714187 \\
\hline & Sphaerocoryne sp. & LT714182 & MH248018 & LT714183 & LT714184 \\
\hline \multirow[t]{6}{*}{ Zancleidae } & Zanclea costata & AY512531 & - & EU876579 & EU879951 \\
\hline & Zanclea sango & LN714107 & LT593889 & LT593874 & LT593869 \\
\hline & Zanclea sp. (DNA-XMZS) & KF962532 & KF962188 & KF962298 & KF962373 \\
\hline & Zanclea prolifera & EU305488 & - & EU272639 & EU272598 \\
\hline & Zanclea sp. 1 & $\begin{array}{l}\text { MH244086, } \\
\text { MH244087, } \\
\text { MH244090, } \\
\text { MH244092, } \\
\text { MH244094, } \\
\text { MH244097 }\end{array}$ & $\begin{array}{l}\text { MH244068, } \\
\text { MH244069, } \\
\text { MH244072, } \\
\text { MH244074, } \\
\text { MH244076, } \\
\text { MH244079 }\end{array}$ & $\begin{array}{l}\text { MH244050, } \\
\text { MH244051, } \\
\text { MH244054, } \\
\text { MH244056, } \\
\text { MH244058, } \\
\text { MH244061 }\end{array}$ & $\begin{array}{l}\text { MH244104, } \\
\text { MH244105, } \\
\text { MH244108, } \\
\text { MH244110, } \\
\text { MH244112, } \\
\text { MH244115 }\end{array}$ \\
\hline & Zanclea sp. 2 & $\begin{array}{l}\text { MH244080-085, } \\
\text { MH244088, } \\
\text { MH244089, } \\
\text { MH244091, } \\
\text { MH244093, } \\
\text { MH244095, } \\
\text { MH244096 }\end{array}$ & $\begin{array}{l}\text { MH244062-067, } \\
\text { MH244070, } \\
\text { MH244071, } \\
\text { MH244073, } \\
\text { MH244075, } \\
\text { MH244077, } \\
\text { MH244078 }\end{array}$ & $\begin{array}{l}\text { MH244044-049, } \\
\text { MH244052, } \\
\text { MH244053, } \\
\text { MH244055, } \\
\text { MH244057, } \\
\text { MH244059, } \\
\text { MH244060 }\end{array}$ & $\begin{array}{l}\text { MH244098-103, } \\
\text { MH244106, } \\
\text { MH244107, } \\
\text { MH244109, } \\
\text { MH244111, } \\
\text { MH244113, } \\
\text { MH244114 }\end{array}$ \\
\hline \multirow[t]{2}{*}{ Outgroups } & Coryne uchidai & GQ395320 & KT981912 & GQ424332 & GQ424306 \\
\hline & Candelabrum cocksii & AY512520 & GU812438 & EU876556 & EU879928 \\
\hline \multicolumn{6}{|c|}{ Sequences used for the $16 \mathrm{~S}$ analysis only } \\
\hline \multirow[t]{8}{*}{ Zancleidae } & Zanclea sessilis & \multicolumn{4}{|c|}{ AY512532, FN687557-558, KP776747, KX355442 } \\
\hline & Zanclea migottoi & \multicolumn{4}{|l|}{ MF538731 } \\
\hline & Zanclea implexa & \multicolumn{4}{|l|}{ KX355448 } \\
\hline & Zanclea sp. (DNA-977) & \multicolumn{4}{|l|}{ KP776810 } \\
\hline & Zanclea sp. (DNA-XMZS) & \multicolumn{4}{|l|}{ KF962533-536 } \\
\hline & Zanclea costata & \multicolumn{4}{|c|}{ EU876553, FN687559 } \\
\hline & Zanclea giancarloi & \multicolumn{4}{|c|}{ FN687560-562, KP776811 } \\
\hline & $\begin{array}{l}\text { Zanclea spp. } \\
\text { (coral-associated) }\end{array}$ & \multicolumn{4}{|c|}{ LN714050, LN714059, LN714064, LN714095, LN714107, LN714110, LT607009 } \\
\hline Milleporidae & Millepora spp. & \multicolumn{4}{|c|}{ KP776777-779, KT891227, KT891230, KT891239, KT891291, KX670777 } \\
\hline Solanderiidae & Solanderia ericopsis & \multicolumn{4}{|l|}{ AY787881 } \\
\hline
\end{tabular}


$60 \mathrm{~min}$, followed by $85^{\circ} \mathrm{C}$ for $15 \mathrm{~min}$, and then directly sequenced in forward and reverse directions using an ABI 3730xl DNA Analyzer (Applied Biosystems). The obtained chromatograms were visually checked and assembled using Sequencher 4.1.4 (Gene Codes). Additionally, COX1 sequences were translated using Geneious 6.1.6 (Drummond et $a l ., 2010)$, in order to check for the presence of stop codons. The sequences obtained were deposited with EMBL (GenBank accession numbers: MH244044MH244115, MH248018, MH248019), including information on specimen vouchers, collection dates, localities, and coordinates. Other available sequences belonging to representatives of the superfamily Zancleida and outgroups (Table 1) were downloaded from GenBank and added to each dataset. Sequences of each marker were aligned with MAFFT 7.110 (Katoh and Standley, 2013) using the E-INS-i option. Two datasets were generated for subsequent analyses. First, all markers were concatenated using Mesquite 3.2 (Maddison and Maddison, 2006), and appropriate partition schemes and models were determined using
PartitionFinder 1.1.1 (Lanfear et al., 2012) by means of the Akaike Information Criterion (AIC) and the Bayesian Information Criterion (BIC). A second dataset was generated through inclusion of all $16 \mathrm{~S}$ $r R N A$ sequences belonging to the family Zancleidae and closely related taxa, since for most zancleid species only this marker was available in GenBank. Phylogenetic inference analyses were performed for the concatenated and $16 \mathrm{~S} r R N A$ datasets using Bayesian inference (BI) and maximum likelihood (ML). BI analyses were performed using MrBayes 3.2.6 (Ronquist et al., 2012): four parallel Markov Chain Monte Carlo runs (MCMC) were run for $10^{7}$ generations, trees were sampled every $100^{\text {th }}$ generation, and burn-in was set to $25 \%$. Maximum likelihood trees were built with RAxML 8.2.9 (Stamatakis, 2014) using 1000 bootstrap replicates. Both BI and ML analyses were run on the CIPRES server (Miller et al., 2010). Genetic distances (uncorrected $p$-distance, 1000 bootstrap) within and among Zancleidae species were computed for the $16 \mathrm{~S}$ rRNA dataset using MEGA 6 (Tamura et al., 2013).

Table 2. Polyp measurements of Zanclea sp. 1 and Zanclea sp. 2.X: absent. Measurements (in $\mu \mathrm{m}$ ) are rounded to the nearest unit and are shown as mean values \pm standard deviations (range).

\begin{tabular}{|c|c|c|}
\hline & Zanclea sp. 1 & Zanclea sp. 2 \\
\hline Hydrorhiza & $\begin{array}{l}\text { Projecting out in roughly spherical clusters, } \\
\text { with euryteles and rarely stenoteles }\end{array}$ & $\begin{array}{l}\text { Projecting out for some of its length, with } \\
\text { euryteles and rarely stenoteles }\end{array}$ \\
\hline Polyp length & $1227 \pm 242(803-1498)$ & $2135 \pm 478(1442-2930)$ \\
\hline Polyp diameter (proximal) & $75 \pm 14(55-80)$ & $125 \pm 20(108-156)$ \\
\hline Polyp diameter (distal) & $113 \pm 19(92-142)$ & $158 \pm 13(106-147)$ \\
\hline $\mathrm{N}^{\circ}$ of oral tentacles & $4-5$ & $4-5$ \\
\hline $\mathrm{N}^{\circ}$ of aboral tentacles & $16-21$ & $23-30$ \\
\hline Oral capitula diameter & $84 \pm 8(74-93)$ & $104 \pm 6(97-117)$ \\
\hline Aboral capitula diameter & $48 \pm 4(41-56)$ & $86 \pm 9(73-104)$ \\
\hline Proximal capitula diameter & $36 \pm 2(32-40)$ & $57 \pm 5(52-65)$ \\
\hline Medusa buds & $1-5$ & $1-6$ \\
\hline Large stenoteles length & $16 \pm 1(15-18)$ & $20 \pm 1(18-22)$ \\
\hline Large stenoteles width & $13 \pm 1(12-14)$ & $16 \pm 2(12-17)$ \\
\hline Medium-sized stenoteles length & $\mathrm{X}$ & $17 \pm 1(15-18)$ \\
\hline Medium-sized stenoteles width & $\mathrm{X}$ & $14 \pm 1(13-15)$ \\
\hline Small stenoteles length & $6 \pm 0(6-7)$ & $7 \pm 0(6-8)$ \\
\hline Small stenoteles width & $5 \pm 1(4-6)$ & $5 \pm 0(4-6)$ \\
\hline Euryteles length & $28 \pm 1(24-29)$ & $20 \pm 1(19-21)$ \\
\hline Euryteles width & $15 \pm 1(11-16)$ & $12 \pm 1(11-14)$ \\
\hline Euryteles shaft length & $92 \pm 5(84-95)$ & $138 \pm 5(134-143)$ \\
\hline
\end{tabular}


Table 3. Medusa measurements of Zanclea sp. 1 and Zanclea sp. 2. X: absent. Measurements (in $\mu$ m) are rounded to the nearest unit and are shown as mean values \pm standard deviations (range).

\begin{tabular}{lll}
\hline & Zanclea sp. 1 & Zanclea sp. 2 \\
\hline Height & $154 \pm 6(152-162)$ & $174 \pm 6(168-180)$ \\
\hline Width & $180 \pm 7(172-191)$ & $208 \pm 6(202-215)$ \\
\hline Manubrium length & $86 \pm 6(79-97)$ & $137 \pm 8(126-146)$ \\
\hline Bunubrium width & $43 \pm 9(33-52)$ & $50 \pm 5(47-57)$ \\
\hline Oral arms length & $85 \pm 9(72-99)$ & $77 \pm 13(56-88)$ \\
\hline Tentacles length & $6 \pm 1(4-7)$ & $5 \pm 1(4-6)$ \\
\hline Cnidophoral pedicels length & $694 \pm 118(561-935)$ & $510 \pm 33(480-560)$ \\
\hline $\mathrm{N}^{\circ}$ of cnidophores & $44 \pm 15(30-70)$ & $31 \pm 6(17-38)$ \\
\hline Cnidophores length & $10-13$ & $11-17$ \\
\hline Cnidophores width & $19 \pm 1(17-21)$ & $20 \pm 2(15-25)$ \\
\hline Mastigophores length & $13 \pm 2(10-17)$ & $17 \pm 1(14-20)$ \\
\hline Mastigophores width & $8 \pm 1(7-9)$ & $8 \pm 1(7-10)$ \\
\hline Mastigophores shaft length & $7 \pm 0(6-7)$ & $7 \pm 1(6-8)$ \\
\hline Euryteles length & $35 \pm 3(30-37)$ & $36 \pm 1(36-37)$ \\
\hline Euryteles width & $6 \pm 1(5-7)$ & $7 \pm 0(6-8)$ \\
\hline Euryteles shaft length & $5 \pm 0(4-6)$ & $5 \pm 0(4-5)$ \\
\hline
\end{tabular}

\section{Results}

\section{Morphology}

Morphological analyses revealed that the collected samples belong to two Zanclea species (here called Zanclea sp. 1 and Zanclea sp. 2) showing several affinities with Zanclella diabolica. Both species were found in the Maldives, whereas Zanclea sp. 2 was also found in the Red Sea. These species live in association with cheilostomate bryozoans and are similar to each other, but morphological and morphometrical analyses revealed differences in the polyp, medusa, and cnidome (Tables 2, 3; Figure 2), as shown in the 'Systematics' section in the Appendix. Specifically, both Zanclea sp. 1 and Zanclea sp. 2 have a perisarcfree hydrorhiza growing under the bryozoan skeleton, projecting out in clusters or for some of its length, and containing macrobasic holotrichous euryteles and stenoteles. Polyps are colonial, monomorphic, and with oral and aboral capitate tentacles with stenoteles of two or three size classes. Medusa buds are borne in clusters on short blastostyles arising directly form the hydrorhiza, and develop in minute medusae. Newly released medusae are characterised by a globular umbrella with several macrobasic holotrichous mastigophores, a manubrium with small oral arms, no exumbrellar nematocyst pouches, two radial canals, and two bulbs bearing tentacles equipped with cnidophores containing macrobasic apotrichous euryteles. The main differences between Zanclea sp. 1 and Zanclea sp. 2 are represented by the size and colour of gastrozooids, the number of aboral tentacles, the type of hydrorhizal projections, the size of euryteles and stenoteles found in the polyp stages, and the length of the manubrium of the medusa stages. These species differ from other Zanclea polyps by the combination of different morphological characters (Supplementary Table S1), including the association with specific organisms, the monomorphic state of the colony, the absence of a perisarc sheet surrounding the hydrorhiza, the position of medusa buds, and the presence, type, and distribution of macrobasic euryteles. They also differ from the highly reduced polyps of Halocoryne and Zanclella, which show zero, one, or two tentacles, with the only exception of the Zanclea-like polyps of Zanclella diabolica. The newly released medusae of Zanclea sp. 1 and Zanclea sp. 2 are very similar to those of Zanclella diabolica and Zanclella glomboides Boero, Bouillon 

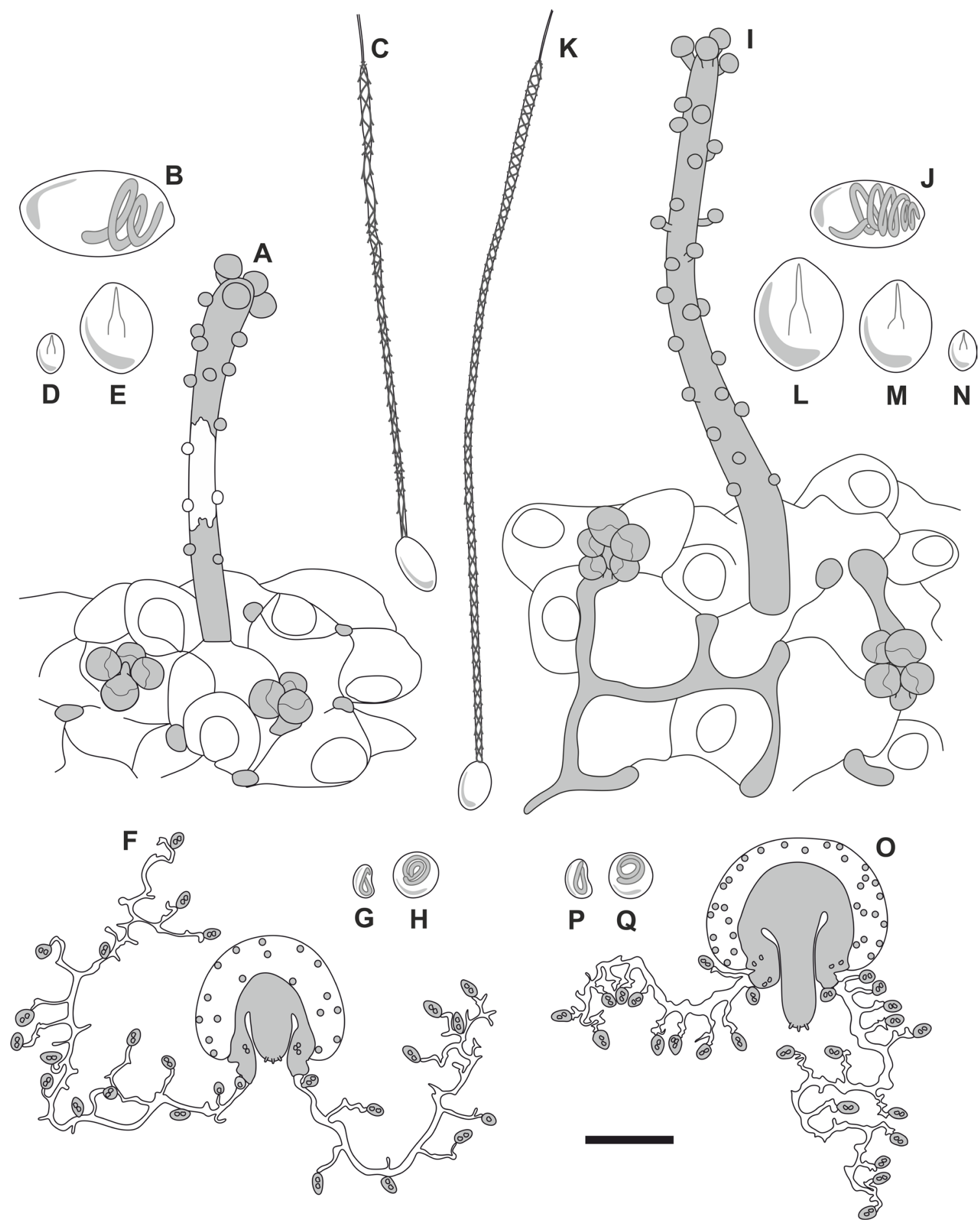

Figure 2. Polyps, medusae, and nematocysts of Zanclea sp. 1 (A-H) and Zanclea sp. 2 (I-Q). Zanclea sp. 1. A: Fertile colony; B, C: Undischarged and discharged macrobasic holotrichous eurytele of the polyp; D, E: Stenoteles of two size classes of the polyp; F: Newly released medusa; G: Macrobasic apotrichous eurytele of the medusa; H: Macrobasic holotrichous mastigophore of the medusa. Zanclea sp. 2. I: Fertile colony; J, K: Undischarged and discharged macrobasic holotrichous eurytele of the polyp; L-N: Stenoteles of three size classes of the polyp; O: Newly released medusa; P: Macrobasic apotrichous eurytele of the medusa; Q: Macrobasic holotrichous

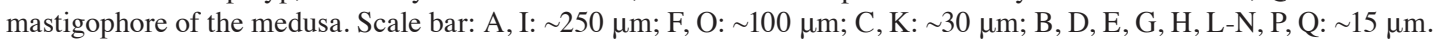


\& Gravili 2000, and highly differ from those known for all other zancleid species (Supplementary Table S2). Comparisons were nevertheless not possible with 12 zancleid species for which only the mature medusa is known (Supplementary Table S2). Therefore it was impossible to identify these specimens to species level and to formally describe Zanclea sp. 1 and Zanclea sp. 2.

\section{Phylogeny and genetic diversity}

The total genomic DNA was successfully extracted and four loci were amplified for all samples. The total alignments of the $16 S$ rRNA, COX1, 18S rRNA, 28S $r R N A$, and concatenated datasets were 569, 607, 1682, 1629 , and 4487 bp long, respectively. PartitionFinder found similar partition schemes and models under the AIC and the BIC. AIC: 16S (GTR+G+I), $18 \mathrm{~S}(\mathrm{GTR}+\mathrm{G}+\mathrm{I}), 28 \mathrm{~S}$ (GTR+G+I), COX1_pos1 $(\mathrm{GTR}+\mathrm{G}), \quad$ COX1_pos2 $\quad$ (GTR), COX1_pos3
$(\mathrm{GTR}+\mathrm{G}+\mathrm{I})$. BIC: 16S (GTR+G+I), 18S (GTR+G+I), 28S (SYM+G+I), COX1_pos1 (GTR+G), COX1_ pos2 (F81), COX1_pos3 (GTR+G). The general topology of the phylogenetic trees based on BI and ML analyses, and computed under both AIC and BIC models and partitions, were similar, and only the Bayesian topologies are shown in Figures 3 and 4. The phylogram of the superfamily Zancleida (Figure 3 ) is mostly concordant with previous works (Maggioni et al., 2016, 2017a). The superfamily Zancleida is well supported (Bayesian posterior probability - BPP $=1$, Maximum likelihood bootstrap support - BS = 77), but the relationships within this group are, in some cases, still uncertain. The less resolved branch of the phylogenetic tree is that composed of the families Asyncorynidae Kramp, 1949, Milleporidae Fleming, 1828, Solanderiidae Marshall, 1892, and Zancleidae. The family Zancleidae appears to be polyphyletic and is split in three divergent lineages, highlighted by stars in Figure 3. A first clade $(\mathrm{BPP}=1, \mathrm{BS}=$

Table 4. Pairwise intra- and inter specific genetic distances (uncorrected $p$-distances in \%) of Zanclea species based on the $16 S$ rRNA. Standard deviations are in parentheses. n.c.: not calculated.

\begin{tabular}{|c|c|c|c|c|c|c|c|c|c|c|c|c|c|}
\hline & & 1 & 2 & 3 & 4 & 5 & 6 & 7 & 8 & 9 & 10 & 11 & 12 \\
\hline 1. & Zanclea sp. 1 & $\begin{array}{c}0.5 \\
(0.2)\end{array}$ & & & & & & & & & & & \\
\hline 2. & Zanclea sp. 2 & $\begin{array}{l}10.5 \\
(1.2)\end{array}$ & $\begin{array}{c}0.4 \\
(0.1)\end{array}$ & & & & & & & & & & \\
\hline 3. & Zanclea costata & $\begin{array}{l}12.4 \\
(1.3)\end{array}$ & $\begin{array}{l}12.1 \\
(1.3)\end{array}$ & $\begin{array}{c}3.7 \\
(0.7)\end{array}$ & & & & & & & & & \\
\hline 4. & Zanclea divergens & $\begin{array}{l}12.7 \\
(1.4)\end{array}$ & $\begin{array}{l}13.6 \\
(1.4)\end{array}$ & $\begin{array}{l}13.1 \\
(1.3)\end{array}$ & n.c. & & & & & & & & \\
\hline 5. & Zanclea giancarloi & $\begin{array}{l}11.7 \\
(1.3)\end{array}$ & $\begin{array}{l}11.7 \\
(1.2) \\
\end{array}$ & $\begin{array}{c}7.1 \\
(1.0) \\
\end{array}$ & $\begin{array}{l}11.2 \\
(1.2) \\
\end{array}$ & $\begin{array}{c}1.0 \\
(0.3) \\
\end{array}$ & & & & & & & \\
\hline 6. & Zanclea implexa & $\begin{array}{l}11.2 \\
(1.3)\end{array}$ & $\begin{array}{l}12.4 \\
(1.3)\end{array}$ & $\begin{array}{c}7.0 \\
(1.0)\end{array}$ & $\begin{array}{l}11.0 \\
(1.2)\end{array}$ & $\begin{array}{c}5.0 \\
(0.8)\end{array}$ & n.c. & & & & & & \\
\hline 7. & Zanclea migottoi & $\begin{array}{l}12.7 \\
(1.3)\end{array}$ & $\begin{array}{l}12.9 \\
(1.3)\end{array}$ & $\begin{array}{c}9.1 \\
(1.1)\end{array}$ & $\begin{array}{l}11.7 \\
(1.3)\end{array}$ & $\begin{array}{c}7.0 \\
(1.0)\end{array}$ & $\begin{array}{c}7.6 \\
(1.0)\end{array}$ & n.c. & & & & & \\
\hline 8. & Zanclea prolifera & $\begin{array}{l}13.7 \\
(1.4) \\
\end{array}$ & $\begin{array}{l}12.4 \\
(1.3) \\
\end{array}$ & $\begin{array}{l}13.9 \\
(1.3) \\
\end{array}$ & $\begin{array}{l}12.7 \\
(1.4)\end{array}$ & $\begin{array}{l}12.7 \\
(1.3) \\
\end{array}$ & $\begin{array}{l}13.2 \\
(1.3) \\
\end{array}$ & $\begin{array}{l}13.2 \\
(1.3)\end{array}$ & n.c. & & & & \\
\hline 9. & Zanclea sessilis & $\begin{array}{l}11.7 \\
(1.3)\end{array}$ & $\begin{array}{l}12.9 \\
(1.3)\end{array}$ & $\begin{array}{c}8.0 \\
(1.1) \\
\end{array}$ & $\begin{array}{l}11.0 \\
(1.2)\end{array}$ & $\begin{array}{c}4.8 \\
(0.8)\end{array}$ & $\begin{array}{c}3.6 \\
(0.7) \\
\end{array}$ & $\begin{array}{c}7.7 \\
(0.7) \\
\end{array}$ & $\begin{array}{l}13.5 \\
(1.3)\end{array}$ & $\begin{array}{c}1.3 \\
(0.3) \\
\end{array}$ & & & \\
\hline 10. & Zanclea sp.(DNA-XMZS) & $\begin{array}{l}12.2 \\
(1.4) \\
\end{array}$ & $\begin{array}{l}13.9 \\
(1.4)\end{array}$ & $\begin{array}{l}10.5 \\
(1.2)\end{array}$ & $\begin{array}{l}13.7 \\
(1.5) \\
\end{array}$ & $\begin{array}{c}8.5 \\
(1.2) \\
\end{array}$ & $\begin{array}{c}9.9 \\
(1.2) \\
\end{array}$ & $\begin{array}{c}8.2 \\
(1.2) \\
\end{array}$ & $\begin{array}{l}13.3 \\
(1.4) \\
\end{array}$ & $\begin{array}{c}9.4 \\
(1.2) \\
\end{array}$ & $\begin{array}{c}0.0 \\
(0.0) \\
\end{array}$ & & \\
\hline 11. & Zanclea sp. (DNA-977) & $\begin{array}{l}10.7 \\
(1.3) \\
\end{array}$ & $\begin{array}{l}12.4 \\
(1.3)\end{array}$ & $\begin{array}{c}7.9 \\
(1.1) \\
\end{array}$ & $\begin{array}{l}10.0 \\
(1.2) \\
\end{array}$ & $\begin{array}{c}5.0 \\
(0.9)\end{array}$ & $\begin{array}{c}3.4 \\
(0.7)\end{array}$ & $\begin{array}{c}8.4 \\
(0.7)\end{array}$ & $\begin{array}{l}12.8 \\
(1.3)\end{array}$ & $\begin{array}{c}3.9 \\
(0.7)\end{array}$ & $\begin{array}{c}9.3 \\
(1.2)\end{array}$ & n.c. & \\
\hline 12. & Coral-associated Zanclea & $\begin{array}{l}13.3 \\
(1.3)\end{array}$ & $\begin{array}{l}14.1 \\
(1.3)\end{array}$ & $\begin{array}{c}11.8 \\
(1.2)\end{array}$ & $\begin{array}{l}11.9 \\
(1.3)\end{array}$ & $\begin{array}{c}9.0 \\
(1.0)\end{array}$ & $\begin{array}{l}10.5 \\
(1.1)\end{array}$ & $\begin{array}{c}9.1 \\
(1.1)\end{array}$ & $\begin{array}{l}15.1 \\
(1.4)\end{array}$ & $\begin{array}{c}9.9 \\
(1.1)\end{array}$ & $\begin{array}{l}10.3 \\
(1.2)\end{array}$ & $\begin{array}{c}9.8 \\
(1.1)\end{array}$ & $\begin{array}{c}4.4 \\
(0.6)\end{array}$ \\
\hline
\end{tabular}




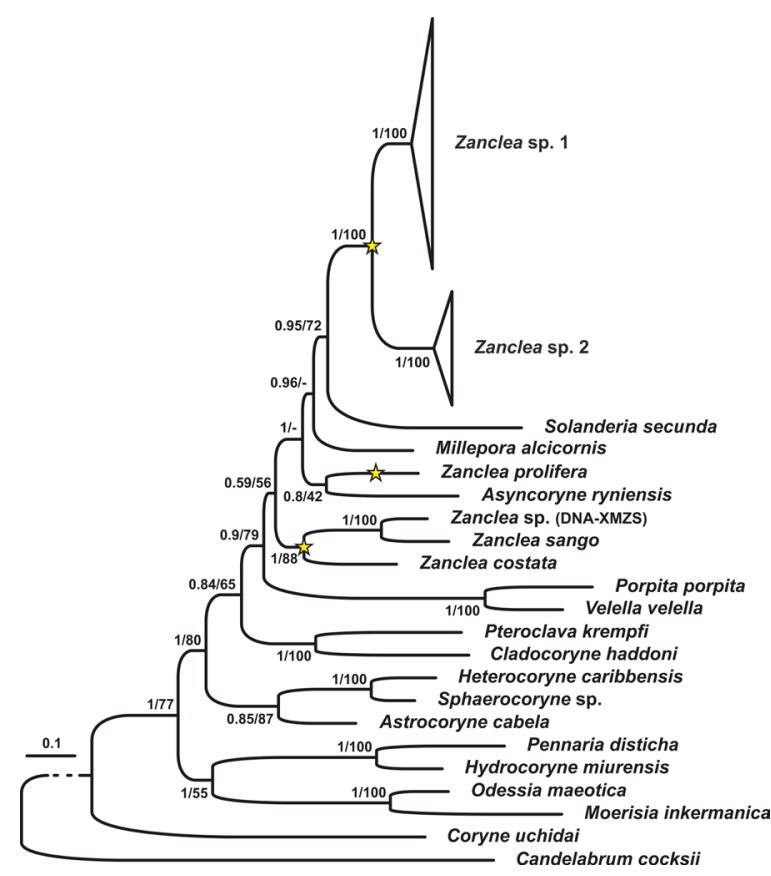

Figure 3. Multi-locus Bayesian phylogram based on the concatenated dataset $16 S$ rRNA-COX1-18S rRNA-28S rRNA of the Zancleida, with Coryne uchidai and Candelabrum cocksii as outgroups. Numbers at nodes show the Bayesian posterior probabilities and the maximum likelihood bootstrapping values, respectively. '-' indicates that a node is not present in BI or ML analyses. Zancleidae lineages are indicated by stars.

88) is composed of the type species Zanclea costata Gegenbaur, 1857, Zanclea sp. (DNA-XMZS) from the China Sea, and coral-associated Zanclea (Zanclea gallii Montano, Maggioni \& Puce, 2015, Zanclea sango Hirose \& Hirose, 2011, and Zanclea spp.). A second clade includes Zanclea prolifera Uchida \& Sugiura, 1976, and is likely to be closely related to Asyncoryne ryniensis Warren, 1908. A third clade $(\mathrm{BPP}=1, \mathrm{BS}=100)$ is represented by the two Zanclea species analysed in this work. They are monophyletic and together form a fully supported cluster. In the phylogenetic hypothesis, they are more closely related to Solanderia secunda (Inaba, 1892) (BPP $=0.92, \mathrm{BS}$ =72), followed by Millepora alcicornis Linnaeus 1758 $(\mathrm{BPP}=0.96, \mathrm{BS}=$ not supported - n. s.) than to the remaining zancleids, even if these latter relationships are generally less supported by ML analysis. The $16 \mathrm{~S}$ rRNA phylogram including all available sequences of the Zancleidae (Figure 4) shows a similar situation, although with low overall statistical supports. The two species of Zanclea herein analysed are monophyletic, and together form a clade with $\mathrm{BPP}=0.83$ and $\mathrm{BS}=$

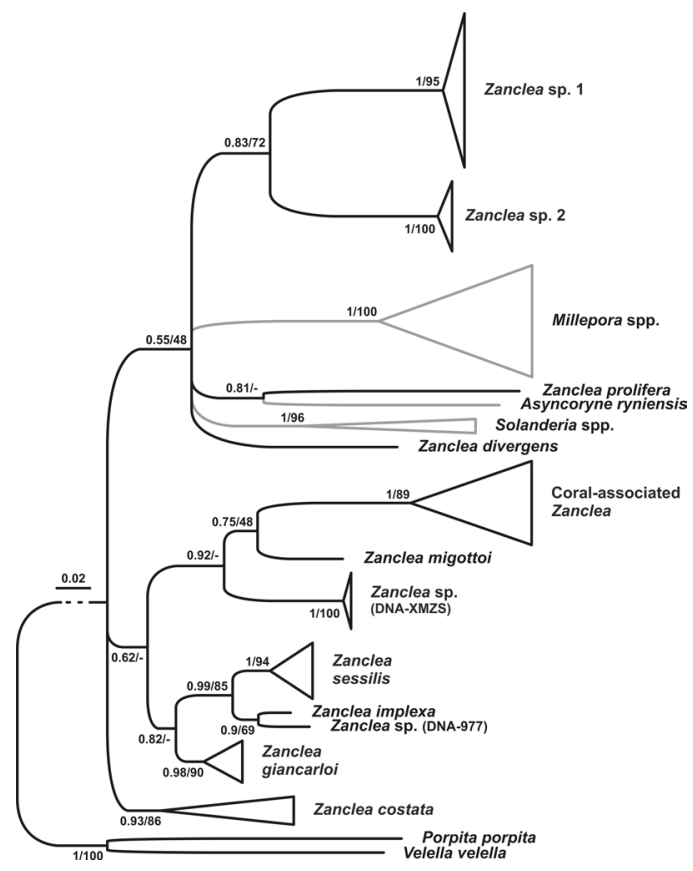

Figure 4. 16S rRNA phylogram of the Zancleidae with Porpita porpita and Velella velella as outgroups. Numbers at nodes show the Bayesian posterior probabilities and the maximum likelihood bootstrapping values, respectively. '-' indicates that a node is not present in BI or ML analyses. Non-Zancleidae taxa are in grey.

72 that falls within a poorly supported group together with Asyncoryne ryniensis, Millepora spp., Solanderia spp., Zanclea prolifera, and Zanclea divergens Boero, Bouillon \& Gravili, 2000 (BPP $=0.55$, BS = 48). Coral-associated Zanclea species cluster with Zanclea sp. (DNA-XMZS), as shown also in Figure 4, and with Zanclea migottoi Galea, 2008 (BPP $=0.92$, $\mathrm{BS}=\mathrm{n}$. s.). The remaining Zanclea species included in the tree are the temperate water Zanclea sessilis (Gosse, 1853), Zanclea giancarloi Boero, Bouillon \& Gravili, 2000, Zanclea implexa (Alder, 1856), and Zanclea sp. (DNA-977), which cluster together (BPP $=0.82, \mathrm{BS}=\mathrm{n}$. s.), and Zanclea costata . Inter-specific genetic distances are high among all species (Table 4). The lowest values are found among the Zanclea species in the temperate water cluster (3.4-5\%), whereas in all other pairwise comparisons values are higher than $7 \%$. Intra-group distances are generally low, with the exception of Zanclea costata (3.7\%) and coral-associated Zanclea (4.4\%), the latter being nevertheless composed of multiple species (Montano et al., 2015b, Maggioni et al., 2017). 


\section{Discussion}

As anticipated by Boero et al. (2000), the family Zancleidae is constantly being enlarged as a result of the descriptions of new species and cryptic taxa (Maggioni et al., 2017b; Pica et al., 2017). Indeed, the integration of in-depth morphological and molecular assessments is helping re-evaluate the diversity of both Zancleidae and closely related families, taking their geographical distributions and host relationships into account if relevant (Montano et al., 2015a, 2015b, 2015c, 2017b; Maggioni et al., 2016, 2017a, 2017b; Takama et al., 2018). Moreover, ecological studies are widening the knowledge of these poorly known organisms (Montano et al., 2016; Dubé et al., 2017a, 2017b). However, the amount of undescribed or cryptic species is probably still high, due to the paucity of diagnostic morphological characters, the often intergrading morphologies (Schuchert, 2010), the incomplete knowledge of life cycles, and the specific associations or behaviour that zancleids often establish and that could, in some cases, make them difficult to spot (Boero and Hewitt, 1992; Boero et al., 2000). Similarly, the outcomes of the symbiotic relationships involving zancleids and the degree of integration with their hosts are still unexplored in most species, although recent studies unveiled patterns of host-specificity (Fontana et al., 2012; Montano et al., 2015 b), characterised the anatomy of the interactions (Pantos and Hoegh-Guldberg, 2011), and discovered previously unsuspected relationships (Montano et al., 2015c, 2017a). Most of the studies have focused on the widespread and more common genus Zanclea, whereas the enigmatic genera Halocoryne and Zanclella have been less investigated, with the latter dealt with in only two earlier works (Boero and Hewitt, 1992; Boero et al., 2000).

In the present study, we analysed two species whose morphology is remarkably similar to Zanclella diabolica. This latter species has typical Zanclea gastrozooids but was originally placed in the genus Zanclella by Boero et al. (2000) because of the peculiar bilateral symmetric bell of the newly released medusa. Indeed, this character is shared with another Zanclella species, Zanclella glomboides, which has nevertheless highly reduced polyps (Boero et al. 2000). The gastrozooids of the type species Zanclella bryozoophila are reduced in the same way, but the sexual stage is completely different from those of the other two Zanclella species, being reduced to eumedusoid (Boero and Hewitt, 1992). This inconsistent intra-generic morphological variability does not allow a secure diagnosis of Zanclella and therefore supports the synonymisation of the genus with Zanclea, at least until a robust phylogenetic hypothesis will clarify this issue. The general reduction of tentacles in Zanclella and Halocoryne gastrozooids may be linked to their behavioural integration with the bryozoan hosts. For instance, the one-tentacled polyps of Zanclella bryozoophila were observed feeding on food particles taken from the host lophophores (Boero and Hewitt, 1992). Furthermore, the atentaculate polyps of H. epizoica were demonstrated to feed on the lophophoral tentacles of the host (Piraino et al., 1992). The convergent evolution of these active and highly specialised feeding mechanisms may have promoted a paralleled progressive reduction of the tentacular structures, making both the reduction of medusae (Petersen, 1990) and polyps ambiguous characters to be used in generic diagnoses. On the other hand, the absence of such an extreme polyp reduction in the two Zanclea species analysed herein, as well as in Zanclella diabolica and all other symbiotic Zanclea species, may reflect a less specialised feeding behaviour of the gastrozooids, which are likely passive predators, as shown, for instance, for Zanclea sessilis and Zanclea giancarloi (Miglietta et al., 2000).

Zanclea sp. 1 and Zanclea sp. 2 are monomorphic, but have a distinctive feature, which is the hydrorhiza projecting out of the bryozoan skeleton. This characteristic is found in a few other zancleids, namely Zanclella diabolica, Zanclea divergens, and Zanclea eilatensis Pica, Bastari \& Puce, 2017. Another species, Zanclea exposita Puce, Cerrano, Boyer, Ferretti \& Bavestrello, 2002, exhibits a perisarc-free hydrorhiza not surrounded by the bryozoan and running above the skeleton of the host (Puce et al., 2002). With the exception of Zanclea eilatensis, these species share the presence of macrobasic holotrichous euryteles in the hydrorhiza, but Zanclea exposita and Zanclea divergens have euryteles also in the gastrozooids, and the latter species produces a typical Zanclea medusa. According to the $16 \mathrm{~S}$ rRNA phylogram, Zanclea divergens, Zanclea sp. 1 and Zanclea sp. 2 seem to belong to a clade diverging from other Zanclea species, and the presence of exposed portions of the perisarc-free hydrorhiza may therefore have taxonomic relevance. The hydrorhizal clusters armed with nematocyst batteries were interpreted by Boero et al. (2000) as a potential first step towards colony polymorphism. If this is true, polymorphism may have arisen independently in divergent lineages within 
the Zancleidae. For instance, Zanclea divergens, the polymorphic coral-associated Zanclea (Montano et al., 2015b), and the facultatively polymorphic Zanclea sessilis (Altuna, 2016) are highly divergent from each other.

The phylogenetic hypotheses presented in this work are concordant in recovering the family Zancleidae and the genus Zanclea as polyphyletic taxa, even if in some cases the nodes are still not fully supported by both Bayesian inference and maximum likelihood analyses. Single- and multi-locus phylogenies show that Zanclea prolifera is more closely related to Asyncoryne ryniensis than to its nominal congeners, even with low statistical support, confirming the findings of previous works (Nawrocki et al., 2010; Maggioni et al., 2017a). Zanclea costata, the type species of the genus Zanclea, clusters with coral-associated Zanclea and Zanclea sp. (DNA-XMZS) from the China Sea in the multi-locus phylogeny, suggesting that these species belong to the 'real' family Zancleidae and to the genus Zanclea. The phylogenetic position of Zanclea costata is still dubious in the single-locus tree, and the placement in Zanclea of Z. giancarloi, Z. sessilis, Z. migottoi, Z. implexa, and Zanclea sp. (DNA-977) needs to be confirmed with further multi-locus analyses. Similarly, the position of Zanclea divergens is not fully resolved in the 16S rRNA phylogram, even if it seems more closely related to Zanclea prolifera, Asyncoryne ryniensis, Millepora spp., Solanderia spp., Zanclea sp. 1 and Zanclea sp. 2. The two latter species are monophyletic and closely related, as suggested by their striking morphological similarities. They form a third, divergent clade of Zanclea in the concatenated analysis, with Solanderia secunda as a sister taxon, demonstrating a further polyphyly of both Zanclea and the Zancleidae.

According to these results,Zanclea sp. 1 and Zanclea sp. 2 may belong to Zanclella or to a new cryptic genus, and even to a new family in the superfamily Zancleida. However, we cautiously refrain from assigning them to Zanclella or from erecting new taxa, at least until genetic data of Zanclella and Halocoryne species will be produced and included in the analyses. Overall, the chaotic taxonomy of the Zancleidae is likely due to the general appearance of the polyps and medusae, which are often similar to those of related taxa (e.g. the gastrozooids are very similar to those of many Solanderia, Millepora and Corynidae species, while the medusae resemble those of Asyncoryne), and this could have contributed to the misplacement of some species and even genera.
Another relevant source of confusion is illustrated by the fact that the complete life cycle is not known for most of the 42 zancleid species. Indeed, 11 species are known only from their adult medusa stage, six from their polyp stage, and 12 from their polyp and newly released medusa stages. This is mostly due to the fact that medusa-based descriptions do not provide any information about the polyp stage and to the difficulty to find fertile colonies and rear the newly released medusa to maturity. These difficulties, along with the prior fragmentary knowledge, the rarity of some species, and the lack of DNA sequences or material suitable for molecular analyses for most taxa, pose a challenge to the resolution of the evolutionary relationships and the systematics of the Zancleidae. Therefore, we stress the need for filling the previous gaps in order to allow a further clarification of the diversity of this enigmatic family.

\section{Acknowledgements}

The authors wish to thank Tullia Terraneo, Malek Amr Gusti, Luca Fallati, Luca Saponari, Inga Dehnert, Enrico Montalbetti, and Bert W. Hoeksema for support during field activities. We thank Prof. Timothy Ravasi as co-organizer of the Farasan Banks Expedition in May 2017. Authors are very grateful to Horia R. Galea, Stefano Piraino, Peter Schuchert, and an anonymous reviewer for their comments and suggestions, which greatly improved this manuscript. This research was undertaken in accordance with the policies and procedures of the King Abdullah University of Science and Technology (KAUST) and the government agencies of the Republic of Maldives. Permissions relevant for KAUST and MaRHE Center to undertake the research have been obtained from the applicable governmental agencies in the Kingdom of Saudi Arabia and the Republic of Maldives, respectively. This project was supported by funding from Università degli Studi di Milano-Bicocca (baseline research funds to PG) and from KAUST (FCC/1/1973 and baseline research funds to MLB).

\section{References}

Agassiz L. 1862. Contributions to the Natural History of the United States of America: Second monograph. Boston: Little, Brown and Co.

Altuna A. 2013. El ciclo vital de Zanclea giancarloi Boero, Bouillon \& Gravili, 2000 (Cnidaria, Hydrozoa, Zancleidae) en la costa vasca (SE Golfo de Vizcaya, Atlántico NE). Munibe 61: 33-46.

Altuna A. 2016. The life cycle of symbiotic Zanclea sessilis (Hydrozoa: Zancleidae) colonies with polymorphic hydranths from the Bay of Biscay. Marine Biodiversity 46: 901-910.

Boero F, Hewitt C. 1992. A hydrozoan, Zanclella bryozoophila n. gen., n. sp.(Zancleidae), symbiotic with a bryozoan, with a 
discussion of the Zancleoidea. Canadian Journal of Zoology 70: 1645-1651.

Boero F, Bouillon J, Gravili C. 2000. A survey of Zanclea, Halocoryne and Zanclella (Cnidaria, Hydrozoa, Anthomedusae, Zancleidae) with description of new species. Italian Journal of Zoology 67: 93-124.

Bouillon J, Gravili C, Gili J-M, Boero F. 2006. An introduction to Hydrozoa. Mémoires du Muséum national d'Histoire naturelle, Paris 194: 1-591.

Browne ET. 1916. Medusae from the Indian Ocean. Transactions of the Linnean Society of London 17: 169-210.

Calder D. 1988. Shallow-water hydroids of Bermuda. The Athecatae. Royal Ontario Museum, Life Sciences Contributions 148: 1-107.

Cerrano C, Amoretti D, Bavestrello G. 1997. The polyp and the medusa of Zanclea costata Gegenbaur (Cnidaria, Hydrozoa). Italian Journal of Zoology 64: 177-179.

Cunningham CW, Buss LW. 1993. Molecular evidence for multiple episodes of paedomorphosis in the family Hydractiniidae. Biochemical Systematics and Ecology 21: 57-69.

Drummond A, Ashton B, Buxton S, Cheung M, Cooper A, Heled J, Kearse M, Moir R, Stones-Havas S, Sturrock S. 2010. Geneious v6. 1.6. http://www.geneious.com.

Dubé CE, Boissin E, Maynard JA, Planes S. 2017a. Fire coral clones demonstrate phenotypic plasticity among reef habitats. Molecular Ecology 26: 3860-3869.

Dubé CE, Mercière A, Vermeij MJ, Planes S. 2017b. Population structure of the hydrocoral Millepora platyphylla in habitats experiencing different flow regimes in Moorea, French Polynesia. PLoS ONE 12: e0173513.

Folmer O, Black M, Hoeh W, Lutz R, Vrijenhoek R. 1994. DNA primers for amplification of mitochondrial cytochrome $c$ oxidase subunit I from diverse metazoan invertebrates. Molecular Marine Biology and Biotechnology 3: 294-299.

Fontana S, Keshavmurthy S, Hsieh HJ, Denis V, Kuo C-Y, Hsu C-M, Leung JK, Tsai W-S, Wallace CC, Chen CA. 2012. Molecular evidence shows low species diversity of coral-associated hydroids in Acropora corals. PLoS ONE 7: e50130.

Galea HR. 2008. On a collection of shallow-water hydroids (Cnidaria: Hydrozoa) from Guadeloupe and Les Saintes, French Lesser Antilles. Zootaxa 1878: 1-54.

Gershwin LA, Zeidler W. 2003. Encounter 2002 Expedition to the Isles of St Francis, South Australia: medusae, siphonophores and ctenophores. Transactions of the Royal Society of South Australia 127: 205-241.

Gravili C, Boero F, Bouillon J. 1996. Zanclea species (Hydroidomedusae, Anthomedusae) from the Mediterranean. Scientia Marina 60: 99-108.

Haeckel E. 1879. Das system der medusen. Jena: Gustav Fischer.

Hastings AB. 1930. On the association of a gymnoblastic hydroid (Zanclea protecta, sp. n.) with various cheilostomatous Polyzoa from the tropical E. Pacific. Annals and Magazine of Natural History (Series 10) 5: 552-560.

Hirohito 1988. The hydroids of Sagami Bay. Tokyo: Publications of the Biological Laboratory Imperial Household.

Hirose M, Hirose E. 2011. A new species of Zanclea (Cnidaria: Hydrozoa) associated with scleractinian corals from Okinawa, Japan. Journal of the Marine Biological Association of the United Kingdom 92: 877-884.

Katoh K, Standley DM. 2013. MAFFT multiple sequence alignment software version 7: improvements in performance and usability. Molecular Biology and Evolution 30: 772-780.

Kramp PL. 1959. Some new and little-known Indo-Pacific medusae. Videnskabelige Meddelelser fra Dansk Naturhistorisk Forening 121: 223-259.

Lanfear R, Calcott B, Ho SY, Guindon S. 2012. PartitionFinder: combined selection of partitioning schemes and substitution models for phylogenetic analyses. Molecular Biology and Evolution 29: 1695-1701.

Maddison WP, Maddison DR. 2006. Mesquite: a modular system for evolutionary analysis. http://www.mesquiteproject.org.

Maggioni D, Montano S, Seveso D, Galli P. 2016. Molecular evidence for cryptic species in Pteroclava krempfi (Hydrozoa, Cladocorynidae) living in association with alcyonaceans. Systematics and Biodiversity 14: 484-493.

Maggioni D, Galli P, Berumen ML, Arrigoni R, Seveso D, Montano S. 2017a. Astrocoryne cabela, gen. nov. et sp. nov. (Hydrozoa: Sphaerocorynidae), a new sponge-associated hydrozoan. Invertebrate Systematics 31: 734-746.

Maggioni D, Montano S, Arrigoni R, Galli P, Puce S, Pica D, Berumen ML. 2017b. Genetic diversity of the Acropora-associated hydrozoans: new insight from the Red Sea. Marine Biodiversity 47: 1045-1055.

Medlin L, Elwood HJ, Stickel S, Sogin ML. 1988. The characterization of enzymatically amplified eukaryotic 16S-like rRNA-coding regions. Gene 71: 491-499.

Miglietta MP, Della Tommasa L, Denitto F, Gravili C, Pagliara P, Bouillon J, Boero F. 2000. Approaches to the ethology of hydroids and medusae (Cnidaria, Hydrozoa). Scientia Marina 64: 63-71.

Migotto AE. 1996. Benthic shallow-water hydroids (Cnidaria, Hydrozoa) of the coast of São Sebastião, Brazil, including a checklist of Brazilian hydroids. Zoologische Verhandelingen, Leiden 306: 1-125.

Miller MA, Pfeiffer W, Schwartz T. 2010. Creating the CIPRES Science Gateway for inference of large phylogenetic trees. Proceedings of the Gateway Computing Environments Workshop (GCE), 2010, New Orleans, IEEE.

Montano S, Arrigoni R, Pica D, Maggioni D, Puce S. 2015a. New insights into the symbiosis between Zanclea (Cnidaria, Hydrozoa) and scleractinians. Zoologica Scripta 44: 92-105.

Montano S, Maggioni D, Arrigoni R, Seveso D, Puce S, Galli P. 2015b. The hidden diversity of Zanclea associated with scleractinians revealed by molecular data. PLOS ONE 10: e0133084.

Montano S, Seveso D, Galli P, Puce S, Hoeksema BW. 2015c. Mushroom corals as newly recorded hosts of the hydrozoan symbiont Zanclea sp. Marine Biology Research 11: 773-779.

Montano S, Allevi V, Seveso D, Maggioni D, Galli P. 2016. Habitat preferences of the Pteroclava krempfi-alcyonaceans symbiosis: inner vs outer coral reefs. Symbiosis 72: 225-231.

Montano S, Fattorini S, Parravicini V, Berumen ML, Galli P, Maggioni D, Arrigoni R, Seveso D, Strona G. 2017a. Corals hosting symbiotic hydrozoans are less susceptible to predation and disease. Proceeding of the Royal Society B: Biological Sciences 284: 20172405.

Montano S, Maggioni D, Galli P, Hoeksema BW. 2017b. A cryptic species in the Pteroclava krempfi species complex (Hydrozoa, Cladocorynidae) revealed in the Caribbean. Marine Biodiversity 47: 83-89.

Nawrocki AM, Schuchert P, Cartwright P. 2010. Phylogenetics and evolution of Capitata (Cnidaria: Hydrozoa), and the sys- 
tematics of Corynidae. Zoologica Scripta 39: 290-304.

Osman RW, Haugsness JA. 1981. Mutualism among sessile invertebrates: a mediator of competition and predation. Science 211: 846-848.

Pantos O, Bythell JC. 2010. A novel reef coral symbiosis. Coral Reefs 29: 761-770.

Pantos O, Hoegh-Guldberg O. 2011. Shared skeletal support in a coral-hydroid symbiosis. PLOS ONE 6: e20946.

Peña Cantero ÁL, Boero F, Piraino S. 2013. Shallow-water benthic hydroids from Tethys Bay (Terra Nova Bay, Ross Sea, Antarctica). Polar Biology 36: 731-753.

Petersen KW. 1990. Evolution and taxonomy in capitate hydroids and medusae (Cnidaria: Hydrozoa). Zoological journal of the Linnean Society 100: 101-231.

Pica D, Bastari A, Vaga CF, Di Camillo CG, Montano S, Puce S. 2017. Hydroid diversity of Eilat Bay with the description of a new Zanclea species. Marine Biology Research 13: 469-479.

Piraino S, Bouillon J, Boero F. 1992. Halocoryne epizoica (Cnidaria, Hydrozoa), a hydroid that 'bites'. Scientia Marina 56: 141-147.

Puce S, Cerrano C, Boyer M, Ferretti C, Bavestrello G. 2002. Zanclea (Cnidaria: Hydrozoa) species from Bunaken Marine Park (Sulawesi Sea, Indonesia). Journal of the Marine Biological Association of the United Kingdom 82: 943-954.

Puce S, Di Camillo CG, Bavestrello G. 2008. Hydroids symbiotic with octocorals from the Sulawesi Sea, Indonesia. Journal of the Marine Biological Association of the United Kingdom 88: 1643-1654.

Ristedt H, Schuhmacher H. 1985. The bryozoan Rhynchozoon larreyi (Audouin, 1826) - A successful competitor in coral reef communities of the Red Sea. Marine Ecology 6: 167179.

Ronquist F, Teslenko M, van der Mark P, Ayres DL, Darling A, Höhna S, Larget B, Liu L, Suchard MA, Huelsenbeck JP. 2012. MrBayes 3.2: efficient Bayesian phylogenetic inference and model choice across a large model space. Systematic Biology 61: 539-542.

Russel F. 1953. The medusae of the British Isles. Cambridge: Cambridge University Press.

Schuchert P. 1996. The marine fauna of New Zealand: athecate hydroids and their medusae (Cnidaria: Hydrozoa). New Zealand Oceanographic Institute Memoir 106: 1-159.

Schuchert P. 2010. The European athecate hydroids and their medusae (Hydrozoa, Cnidaria): Capitata part 2. Revue Suisse de Zoologie 117: 337-555. DOI: 10.5962/bhl.part.117793.

Stamatakis A. 2014. RAxML version 8: a tool for phylogenetic analysis and post-analysis of large phylogenies. Bioinformatics 30: 1312-1313.

Takama O, Fernandez-Silva I, Lopez C, Reimer JD. 2018. Molecular phylogeny demonstrates need for taxonomic reconsideration of species diversity of the hydrocoral genus Millepora (Cnidaria: Hydrozoa) in the Pacific. Zoological Science 35: 123-133.

Tamura K, Stecher G, Peterson D, Filipski A, Kumar S. 2013. MEGA6: Molecular Evolutionary Genetics Analysis version 6.0. Molecular Biology and Evolution 30: 2725-2729.

Uchida T, Sugiura Y. 1976. On a hydromedusa, Zanclea prolifera n. sp., of which the medusa gives rise to medusa-buds. Proceedings of the Japan Academy 52: 141-144.

Varela C. 2012. Registros nuevos de hidrozoos (Cnidaria: Hydroidomedusae) para Cuba, con la descripción de una espe- cie nueva. Solenodon 10: 1-7.

Xu Z, Huang J, Chen X. 1991. On new species and record of Hydromedusae in the upwelling region off the Minnan-Taiwan Bank fishing ground, China. Beijing: Minnan-Taiwan Bank Fishing Ground Upwelling Ecosystem Study.

Xu Z, Huang J, Guo D. 2008. Six new species of Anthomedusae (Hydrozoa, Hydroidomedusae) from the Beibu Gulf, China. In Symposium on Oceanography of the Beibu Gulf China (pp. 209-221). Beijing: Ocean Press.

Zietara MS, Arndt A, Geets A, Hellemans B, Volckaert FA. 2000. The nuclear rDNA region of Gyrodactylus arcuatus and G. branchicus (Monogenea: Gyrodactylidae). Journal of Parasitology 86: 1368-1373.

Received: 19 February 2018

Revised and accepted: 5 May 2018

Published online: 20 August 2018

Editor: B.W. Hoeksema

\section{Online supplementary material}

S1. Polyp stage characteristics of all nominal zancleid species, Zanclea sp. 1, and Zanclea sp. 2. * Data obtained from drawings in original descriptions.

S2. Medusa stage characteristics of all nominal zancleid species, Zanclea sp. 1, and Zanclea sp. 2. * Data obtained from drawings in original descriptions.

S3. Polyp stage characteristics of all nominal zancleid species, Zanclea sp. 1, and Zanclea sp. 2. * Data obtained from drawings in original descriptions.

S4. Medusa stage characteristics of all nominal zancleid species, Zanclea sp. 1, and Zanclea sp. 2. * Data obtained from drawings in original descriptions. 


\section{Appendix}

\section{Systematics}

Class Hydrozoa Owen, 1843

Order Anthoathecata Cornelius, 1992

Suborder Capitata Kühn, 1913

Family Zancleidae Russel, 1953

Genus Zanclea Gegenbaur, 1856

\section{Zanclea sp. 1}

Material examined. Polyp stage. MA0216061: Wall Street Reef, Faafu Atoll, Maldives $\left(3.12061^{\circ} \mathrm{N}\right.$, 73.09581 $\left.{ }^{\circ} \mathrm{E}\right), 10 / 02 / 2016,19 \mathrm{~m}$ depth. MA0316014: Blue Cove, Faafu Atoll, Maldives $\left(3.09383^{\circ} \mathrm{N}\right.$, 72.96651 $\left.{ }^{\circ} \mathrm{E}\right), 09 / 03 / 2016,20 \mathrm{~m}$ depth. MA0316101: Route 66 Reef, Faafu Atoll, Maldives $\left(3.07717^{\circ} \mathrm{N}\right.$, 72.97328 $\left.{ }^{\circ} \mathrm{E}\right), 21 / 03 / 2016,8 \mathrm{~m}$ depth. MA0316171: Blue Cove, Faafu Atoll, Maldives $\left(3.09383^{\circ} \mathrm{N}\right.$, 72.9665 $\left.{ }^{\circ} \mathrm{E}\right), 22 / 03 / 2016,20 \mathrm{~m}$ depth. MA1016034: Wall Street Reef, Faafu Atoll, Maldives $\left(3.12061^{\circ} \mathrm{N}\right.$, 73.09581 $\left.{ }^{\circ} \mathrm{E}\right), 16 / 10 / 2016,17 \mathrm{~m}$ depth. MA0117058: Sunny Reef, Faafu Atoll, Maldives $\left(3.14294^{\circ} \mathrm{N}\right.$, 73.01206 ${ }^{\circ}$ ) , 04/02/2017, 20 m depth. MA0117174: Route 66 Reef, Faafu Atoll, Maldives $\left(3.07717^{\circ} \mathrm{N}\right.$, $\left.72.97328^{\circ} \mathrm{E}\right), 21 / 02 / 2017,5 \mathrm{~m}$ depth. Medusa stage. MA021661B: 2-day-old medusae released from sample MA0216061.

Diagnosis. Polyps monomorphic, with 4-5 oral and 16-21 aboral capitate tentacles and a typical white band in the middle or in proximal part of the column. Hydrorhiza projecting out of the bryozoan skeleton with clusters of nematocysts. At release, medusa laterally compressed, with two tentacular bulbs bearing opposite tentacles; manubrium reaching the velar opening, mouth with oral arms.

Description of the polyp. Colony stolonal, growing in association with cheilostomate bryozoans (Figures 2A, 5A). Hydrorhiza devoid of a perisarc sheet, reticular, crawling under the bryozoan skeleton, often projecting out at the corners of zooeciae with clusters of nematocysts (Figures 2A, 5B). Polyps monomorphic. Gastrozooids tubular, up to $1.5 \mathrm{~mm}$ long, $55-80 \mu \mathrm{m}$ wide proximally and 92-142 $\mu \mathrm{m}$ distally. Mouth distal and circular, surrounded by 4-5 short oral tentacles; 16-21 additional, aboral tentacles scattered irregularly-spirally over $2 / 3^{\text {rd }}$ of the polyp column, comparatively shorter than their oral counterparts, occasionally represented by sessile capitula only (Figures 2A, 5C-D). Capitula with nematocysts and with inclusions (Figure 5E), bigger in oral tentacles (74-93 $\mu \mathrm{m})$, and decreasing in size proximally (32-56 $\mu \mathrm{m})$ (Figures 2A, 5C-D). Living polyps transparent, with a whitish mouth, an orange hypostome, and a typical white band in the middle or proximal half of the polyp (Figures 5A, C-D), which disappears in fixed material. Medusa buds minute, originating from the protruding hydrorhiza, and grouped in clusters of 1-5 (Figures 2A, 5F). Cnidome composed of stenoteles of two size classes (Figures 2D-E, 5G) and macrobasic holotrichous euryteles (Figures 2B-C, 5H-I). Large stenoteles (14.5-17.5 x 11.5-14 $\mu \mathrm{m})$ in oral capitula and rarely in aboral capitula, hydrorhiza, and nematocyst clusters. Small stenoteles (5.5-7.5 $\mathrm{x}$ 4-6.5 $\mu \mathrm{m}$ ) in all capitula, and rarely in hydrorhiza. Macrobasic holotrichous euryteles with shaft coiling along the short axis (24.5-29 x 11-16.5 $\mu \mathrm{m}$, discharged shaft: $84-95 \mu \mathrm{m}$ ) abundant in hydrorhiza and in its projections.

Description of the newly released medusa. When released, medusae motionless for several hours. After about 10 hours, tentacles become projected outside the bell cavity. Newly released medusae small, globular, 152-162 $\mu \mathrm{m}$ high and 172-191 $\mu \mathrm{m}$ wide (Figures 2F, 5J-K). Several nematocysts scattered over the exumbrella. Manubrium 79-97 $\mu \mathrm{m}$ long and 33-52 $\mu \mathrm{m}$ wide, reaching the velar opening, with a terminal circular mouth with 3-4 arms 4-7 $\mu$ m long (Figures 2F, 5L). Two opposite tentacular bulbs, initially projecting inside the bell cavity, and everted after two days. Each bulb bearing a tentacle up to $935 \mu \mathrm{m}$ long, armed with 10-15 oval, hairy cnidophores (17-21 x 10-17 $\mu \mathrm{m})$ borne on 30-70 $\mu \mathrm{m}$ long pedicels (Figures $2 \mathrm{~F}, 5 \mathrm{M}$ ). Each cnidophore containing 2 nematocysts. Living medusae transparent, with an orange manubrium basally, white distally (Figure 5K). After one week of cultivation, medusae with slightly longer tentacles but not displaying other differences. Adult, mature medusae not observed. Cnidome composed of macrobasic holotrichous mastigophores (Figures $2 \mathrm{H}$, $5 \mathrm{~N}-\mathrm{O}$ ) and macrobasic apotrichous euryteles (Figures 2G, 5P-Q). Macrobasic holotrichous mastigophores (7-8.5 x 6-7.5 $\mu \mathrm{m}$, discharged shaft: $30.5-36.5 \mu \mathrm{m}$ ) scattered over the exumbrella; macrobasic apotrichous euryteles (5-7 x 3.5-6 $\mu \mathrm{m}$, discharged shaft: 33-39 $\mu \mathrm{m})$ in cnidophores and tentacular bulbs.

Distribution. Known from Faafu Atoll, Maldives.

Taxonomic remarks. Zanclea sp. 1 is strikingly similar to Zanclella diabolica, but it nevertheless 

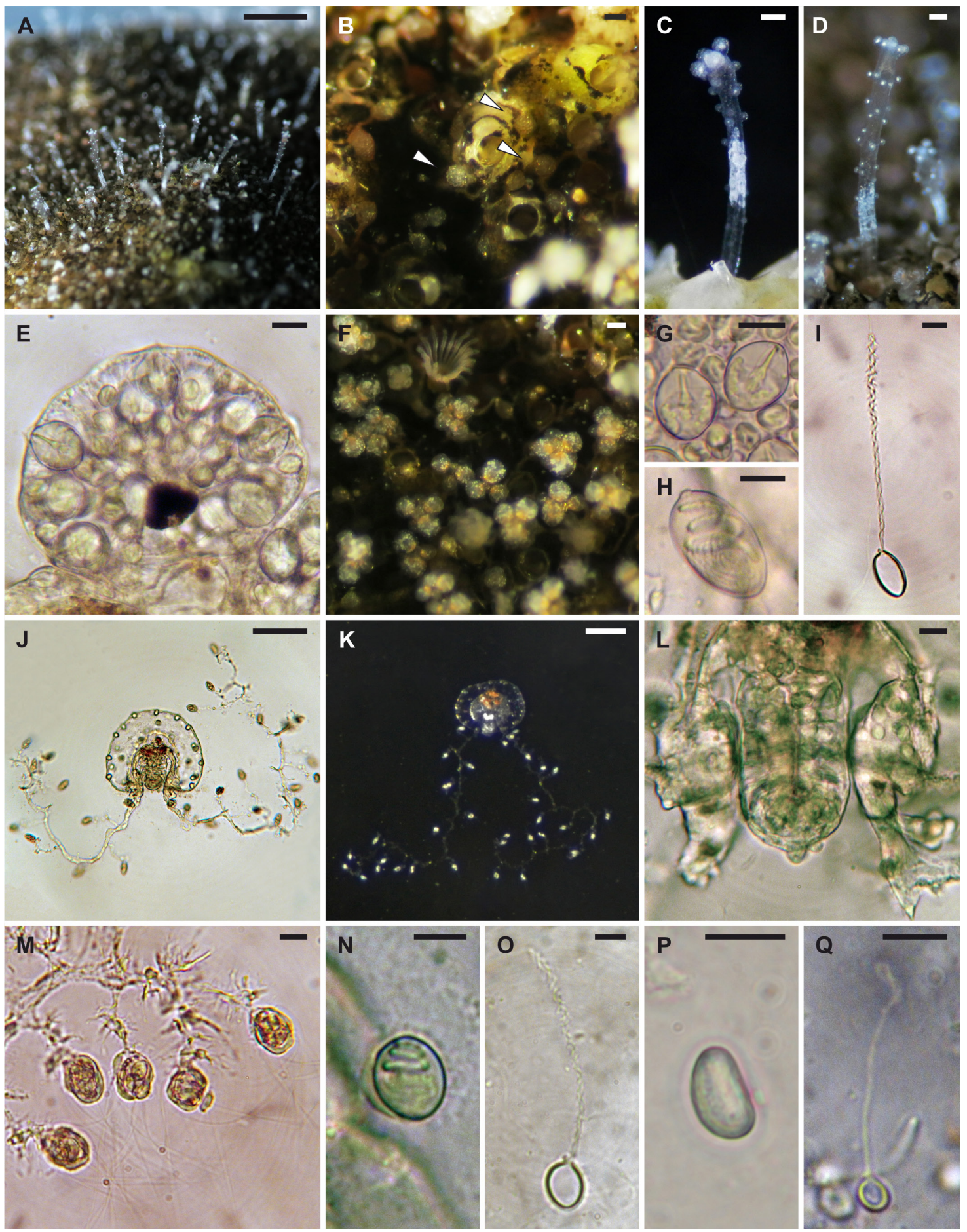

Figure 5. Polyp (A-I) and medusa (J-Q) of Zanclea sp. 1. A: General aspect of a colony; B: Clusters of nematocysts projecting out of the bryozoan skeleton (arrowheads); C,D: Gastrozooids; E: Aboral capitulum showing nematocysts and a central inclusion; F: Medusa buds arising from hydrorhiza; G: Stenoteles of two size classes; H, I: Undischarged and discharged macrobasic holotrichous euryteles, respectively; J, K: Newly released medusae; L: Manubrium ending in a terminal mouth with oral arms; M: Cnidophores; N, O: Undischarged and discharged macrobasic holotrichous mastigophores, respectively; P, Q: Undischarged and discharged macrobasic apotrichous euryteles, respectively. Scale bars: A: 1.5 mm; B-D, F, J, K: $100 \mu \mathrm{m}$; E, G-I, L, M: $10 \mu \mathrm{m}$; N-Q: $5 \mu \mathrm{m}$. 
shows some distinguishing features (Tables 2, 3, Supplementary Tables S1, S2). In particular, the polyps of Zanclea sp. 1 have a higher number of aboral tentacles, a distinct white band on their column, nematocyst clusters containing euryteles and rarely stenoteles, in contrast with Zanclella diabolica, which contains three stenoteles according to Boero et al. (2000). Additionally, all nematocysts in the polyp stage of Zanclea sp. 1 are smaller than in Zanclella diabolica, and the mouth of the medusa is equipped with oral arms. No other zancleid medusae show this latter feature, which could be a synapomorphy shared by Zanclea sp. 1 and Zanclea sp. 2. Alternatively, the oral arms may have gone unnoticed in other zancleid species due to their extremely small size. At this stage, it is not clear whether the morphological differences between Zanclea sp. 1 and Zanclella diabolica represent intra- or inter-specific divergence, and only a thorough re-analysis of material from the type locality and its inclusion in molecular analyses will address this issue.

\section{Zanclea sp. 2}

Material examined. Polyp stage. FB002, FB015, FB018: Abu Latt Island, Al Lith, Saudi Arabia $\left(19.94617^{\circ} \mathrm{N}, \quad 40.15102^{\circ} \mathrm{E}\right), \quad 30 / 04 / 2017, \quad 3 \mathrm{~m}$ depth. FB476: Sofia's Reef, Al Lith, Saudi Arabia $\left(19.79325^{\circ} \mathrm{N}, \quad 40.40007^{\circ} \mathrm{E}\right), \quad 07 / 05 / 2017, \quad 15 \mathrm{~m}$ depth. KA119: Tahla Reef, Thuwal, Saudi Arabia $\left(22.27501^{\circ} \mathrm{N}, 39.04715^{\circ} \mathrm{E}\right), 14 / 12 / 2015,11 \mathrm{~m}$ depth. KA133: Abu Gishaa Reef, Thuwal, Saudi Arabia $\left(22.42706^{\circ} \mathrm{N}, 39.05111^{\circ} \mathrm{E}\right), 16 / 12 / 2015,17 \mathrm{~m}$ depth. MA0216066: Dighu Reef, Faafu Atoll, Maldives $\left(3.08025^{\circ} \mathrm{N}, 72.98269^{\circ} \mathrm{E}\right), 13 / 02 / 2016,20 \mathrm{~m}$ depth. MA1016036: Wall Street Reef, Faafu Atoll, Maldives $\left(3.12061^{\circ} \mathrm{N}, 73.09581^{\circ} \mathrm{E}\right), 16 / 10 / 2016,19 \mathrm{~m}$ depth. MA0117130, MA0117144: Kika Reef, Faafu Atoll, Maldives $\left(3.08702^{\circ} \mathrm{N}, 72.95581^{\circ} \mathrm{E}\right), 13 / 02 / 2017,14$ $\mathrm{m}$ depth. Medusa stage. MA0216066B: 2-day-old medusae released from sample MA0216066.

Diagnosis. Polyps monomorphic, with 4-5 oral and 23-30 aboral capitate tentacles. Hydrorhiza projecting out of the bryozoan skeleton for some of its length. At release, medusa laterally compressed, with two tentacular bulbs bearing opposite tentacles; manubrium long, protruding from the velar opening, mouth with oral arms.

Description of the polyp. Colony stolonal, monomorphic, living in association with cheilostomate bryozoans (Figures 2I, 6A). Hydrorhiza naked, reticular, partially crawling under the bryozoan skeleton and partially projecting out for some of its length at the borders of zooeciae (Figures 2I, 6B). Gastrozooids cylindrical, up to $3 \mathrm{~mm}$ long, 106-147 $\mu \mathrm{m}$ wide at base and 108-156 $\mu \mathrm{m}$ wide distally, with an apical circular mouth, 4-5 oral tentacles and 23-30 aboral tentacles arranged spirally over the distal $3 / 4^{\text {th }}$ of the polyp (Figures 2I, 6C). Tentacles short and reduced to sessile capitula in proximal part, their terminal capitations with nematocysts and inclusions (Figure 6.D). Oral tentacles with larger capitula (97-117 $\mu \mathrm{m})$ and aboral tentacles with comparatively smaller capitula $(52-104 \mu \mathrm{m})$, decreasing in size towards base of polyp (Figures 2I, 6C). Living polyps transparent (Figures 6A, C). Medusa buds minute, borne on short blastostyles arising directly from the projected hydrorhiza and grouped in clusters of up to 6 buds (Figures 2I, 6E). Cnidome composed of stenoteles of three size classes (Figures 2L-N, 6F) and macrobasic holotrichous euryteles (Figures 2J-K, 6G-H). Large stenoteles (18.5-21.5 x 12-17 $\mu \mathrm{m})$, medium-sized stenoteles (15-18 x 12.5-14.5 $\mu \mathrm{m})$ and small stenoteles (6-7.5 x 4-6 $\mu \mathrm{m})$ in capitula and rarely in hydrorhiza; macrobasic holotrichous euryteles with shaft coiling along the short axis (18.5-21 x 11.5-14 $\mu \mathrm{m}$, discharged shaft: 134-143 $\mu \mathrm{m}$ ) abundant in hydrorhiza.

Description of the newly released medusa. At release, medusae motionless for several hours and projecting tentacles outside the bell cavity after about 10 hours. Newly released medusae small, globular, 168-180 $\mu \mathrm{m}$ high and 202-215 $\mu \mathrm{m}$ wide (Figures 2O, $6 \mathrm{I}-\mathrm{J})$. Exumbrella with several scattered nematocysts. Manubrium 126-146 $\mu \mathrm{m}$ long and 47-57 $\mu \mathrm{m}$ wide, protruding from the bell cavity, with a terminal circular mouth with 4-5 arms 4-6 $\mu \mathrm{m}$ long (Figures 2O, 6K). Two opposite bulbs everted from the bell cavity after two days and bearing two tentacles up to $560 \mu \mathrm{m}$ long, armed with 11-17 oval and hairy cnidophores (15-25 x $14-20 \mu \mathrm{m}$ ) borne on 17-38 $\mu \mathrm{m}$ long pedicels (Figures $2 \mathrm{O}, 6 \mathrm{~L})$. Each cnidophore with 1-3 nematocysts. Living medusae transparent, with manubrium orange proximally, and whitish for most of its length (Figure $6 \mathrm{~J})$. After one week of cultivation, medusae with slightly longer tentacles and no other differences. Adult, mature medusae not observed. Cnidome composed of macrobasic holotrichous mastigophores (Figures 2Q, $6 \mathrm{M}-\mathrm{N}$ ) and macrobasic apotrichous euryteles (Figures 2P, 6O-P). Macrobasic holotrichous mastigophores (7$10 \times 6-8.5 \mu \mathrm{m}$, discharged shaft: $35.5-37 \mu \mathrm{m}$ ) scattered over the exumbrella; macrobasic apotrichous euryteles 

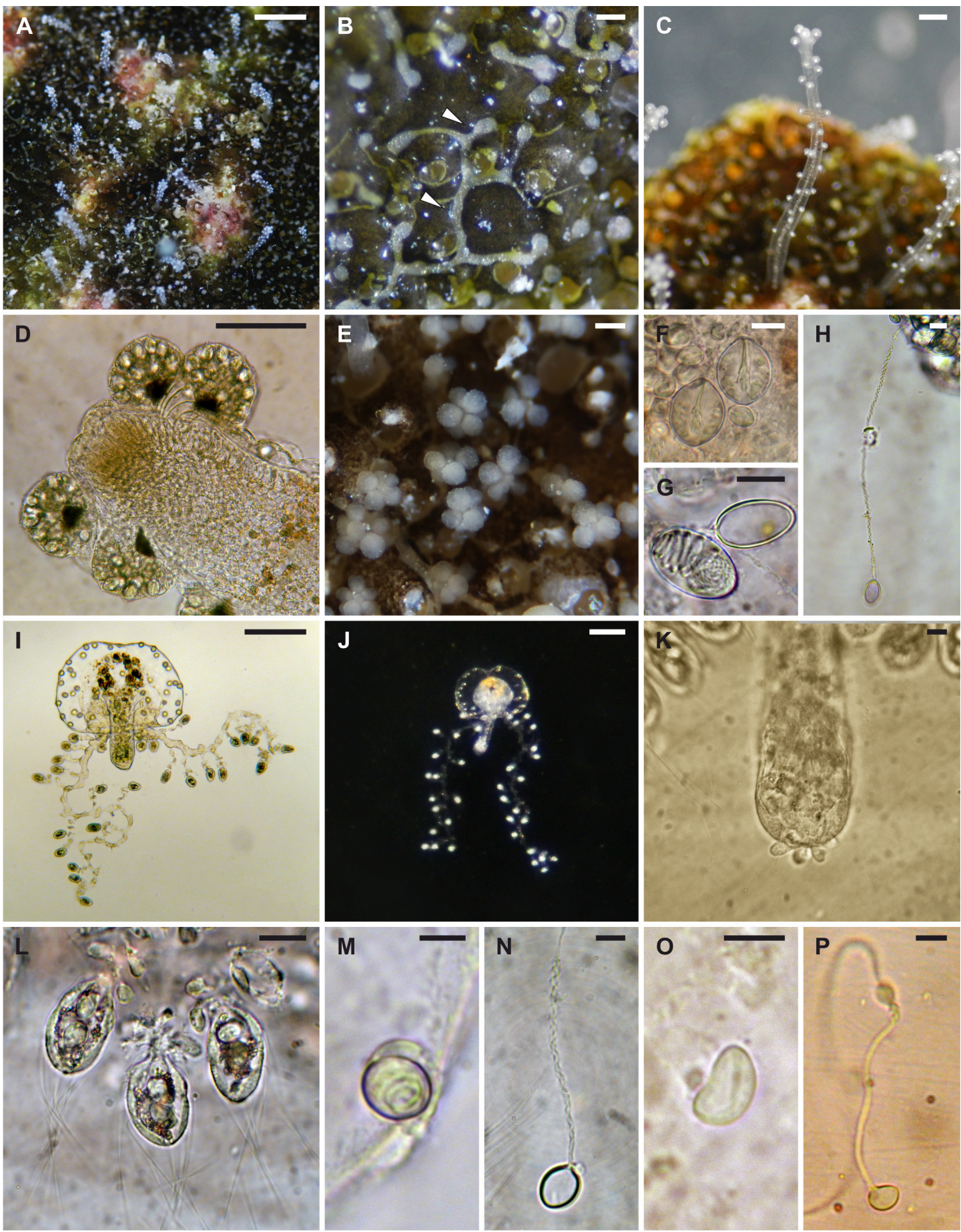

Figure 6. Polyp (A-H) and medusa (I-P) of Zanclea sp. 2. A: General aspect of a colony; B. Hydrorhiza partially extruding at the surface of the bryozoan host (arrowheads); C. Gastrozooids; D. Apical portion of a gastrozooid, showing four oral tentacles with nematocysts and central inclusions; E: Medusa buds arising from the exposed hydrorhiza; F: Large and small stenoteles; G, H: Undischarged and discharged macrobasic holotrichous euryteles, respectively; I, J: Newly released medusae; K: Terminal part of the manubrium showing a mouth with five arms; L: Cnidophores; M, N: Undischarged and discharged macrobasic holotrichous mastigophores, respectively; O, P: Undischarged and discharged macrobasic apotrichous euryteles, respectively. Scale bars: A: 1.5 mm; B, C: $200 \mu \mathrm{m}$; D, E, I, J: $100 \mu \mathrm{m} ; \mathrm{F}, \mathrm{G}, \mathrm{H}, \mathrm{K}, \mathrm{L}: 10 \mu \mathrm{m}$; M-P: $5 \mu \mathrm{m}$. 
(6-8 x 4-5.5 $\mu \mathrm{m}$, discharged shaft: $37.5-39.5 \mu \mathrm{m}$ ) in cnidophores and tentacular bulbs.

Distribution. Known from Faafu Atoll (Maldives), Thuwal and Al Lith (Red Sea, Saudi Arabia).

Taxonomic remarks. Zanclea sp. 2 and Zanclea sp. 1 are similar to Zanclella diabolica in both the polyp and medusa stages. These species have Zanclea-like polyps, hydrorhizae projecting out of the bryozoan skeleton, minute medusa buds borne on small pedicels given off from the hydrorhiza, newly released medusae small, globular, and a similar cnidome. However, some diagnostic differences are found in both the polyp and medusa stages (Tables 2, 3, Supplementary Tables S1, S2). The hydrorhizae in Zanclella diabolica and Zanclea sp. 1 show nematocyst clusters with a more regular and approximately spherical shape, whereas in Zanclea sp. 2 the hydrorhiza projects out of the bryozoan skeleton in a more irregular way and for some of its length. Moreover, the polyps in Zanclea sp. 2 are longer and have generally more tentacles than the other two species. Other differences are found in the size of the polyp nematocysts, as Zanclea sp. 2 has stenoteles of three size classes (instead of two) and smaller euryteles with a shaft length in-between the other two species. Also, the medusa of Zanclea sp. 2 has a longer manubrium extending further out of the velar aperture. The morphological differences between Zanclea sp. 1 and Zanclea sp. 2 are well supported by phylogenetic and genetic distance analyses, since these two species form two fully supported monophyletic clusters. 